\title{
From Divine Instruction to Human Invention: The Constitution of Indonesian Christian Young People's Sexual Subjectivities through the Dominant Discourse of Sexual Morality
}

\section{Teguh Wijaya Mulya}

To cite this article: Teguh Wijaya Mulya (2018): From Divine Instruction to Human Invention: The Constitution of Indonesian Christian Young People's Sexual Subjectivities through the Dominant Discourse of Sexual Morality, Asian Studies Review, DOI: 10.1080/10357823.2017.1407918

To link to this article: https://doi.org/10.1080/10357823.2017.1407918

曲 Published online: 07 Jan 2018.

Submit your article to this journal $₫$

Q View related articles $\sqsubset$

View Crossmark data $\asymp$ 


\title{
From Divine Instruction to Human Invention: The Constitution of Indonesian Christian Young People's Sexual Subjectivities through the Dominant Discourse of Sexual Morality
}

\author{
Teguh Wijaya Mulya
}

University of Surabaya

\begin{abstract}
Based on a study of 22 young people aged $16-24$ years old, this article examines the constitution of young Indonesian Christians' sexual subjectivities through the dominant discourse of sexual morality. It is concerned with how this discourse has been drawn on and resisted as these young people become sexual subjects. I argue that the dominant discourse of sexual morality has positioned Indonesian young people within a binary of being either "moral" (maintaining heterosexual abstinence until marriage) or "immoral" (engaging in sex), to the extent that other ethical sexual relationships and pleasures become unthinkable. This article also provides evidence that the dominant discourse of sexual morality has been contested in the constitution of Indonesian Christian young people as sexual subjects. Three alternative ways in which participants resist the religious sexual moral codes imposed upon them are discussed, namely: casting off religion altogether, reinterpreting religious morality, and practising a double morality.
\end{abstract}

\section{KEYWORDS}

Sexual subjectivity; religion; morality; Indonesia; youth;

Christianity

\section{Introduction}

Discourses of morality have become critical in the regulation of gender and sexuality in Indonesia's post-1998 reformasi era (Platt, Davies, \& Bennett, 2018). Following Foucault's (1982) interest in revealing how power makes individuals into subjects, this article investigates how moral discourse as an expression of power operates in the (re)production of young Indonesians' sexual subjectivities. Specifically, it seeks to examine how young Indonesians have engaged with, negotiated and resisted the dominant discourse of morality in their discussions about themselves as sexual beings. I present six cases to illustrate different ways of being sexual vis-à-vis the discourse of morality among young people in contemporary Indonesia. This contribution extends previous studies that have mainly been conducted among Indonesian Muslims (Bennett, 2007; Boellstorff, 2005; S.G. Davies, 2011; Kailani, 2012; Parker, 2009; 2014; Smith-Hefner, 2005; 2006; van Wichelen, 2010), by exploring the interplay between religion, morality and sexual subjectivity in the context of young Indonesian Christians (i.e. Catholics and Protestants). 
In Muslim-majority Indonesia, the dominant discourse of sexual morality has constituted young people's sexual practice as primarily a moral problem because any sexual relationship outside (heterosexual) marriage is deemed “immoral” (Bennett, 2007; Parker, 2009; 2014; Smith-Hefner, 2006). An example of how this discourse manifests in Indonesian everyday social practices is the moral panic surrounding Indonesian young people's socialising and engaging in sex (pergaulan bebas), which has been widely circulated through educational guide books, family planning posters, teen magazines, movies and advertisements to which young people have access (Harding, 2008; Webster, 2010). Scare tactics, such as warnings of the health risk of unsafe abortion or the shame their family could suffer if young people were pregnant out of wedlock, are frequently deployed in these mediums to discourage youth from pergaulan bebas. Subject positions offered to Indonesian young people within this discourse are either those considered to be "moral" (involving abstinence before marriage) or those rendered "immoral" (where sex outside heterosexual marriage takes place).

Through various mechanisms of censorship, surveillance and punishment - which are endorsed by the state, local communities and religious institutions - Indonesian youth are urged to take up the moral subject position. From time to time, the media report on raids carried out by both neighbours and the police to catch unmarried (heterosexual) young people engaging in consensual sex, whether in their own homes, rented rooms or motels (e.g. S.G. Davies, 2015; Haq, 2016). The police also conduct schoolbag inspections at Internet cafés and schools searching for pornography - declared illegal and actively censored since 2008 (Lim, 2013; Surya, 2016; “Undang-undang”, 2008). Conservative Muslim groups often condemn sexuality education initiatives, claiming that they encourage the "immoral" practice of premarital sex and promote LGBT+ (lesbian, gay, bisexual, transgender and other) identities. An example of strong opposition to sexuality education can be seen in the Ministry of Health's decision to cancel a condom-awareness program after protests by conservative Muslim groups (Natahadibrata, 2013). These examples indicate that attempts to discipline young people into becoming abstinent (hetero-)sexual moral subjects are prevalent in Indonesia. In order to contest this dominant discourse of sexual morality, I investigate how Indonesian youth engage in practices of resistance; that is, how they cultivate alternative ways of being sexual despite the homogenising and moralising political-legal-social practices and institutions.

Foucault $(1978 ; 1982)$ argues that modern power does not operate or govern society in a repressive top-down fashion, but through circulations of certain discourses and in conjunction with individuals' exercise of agency. The meanings of sexuality and (im/)moral subject positions offered by the dominant discourse of sexual morality do not take effect until they are taken up by individuals, such as by young people themselves in understanding their sexual selves - which in Indonesia is also often conflated with their religious selves. Previous research with young Indonesian Muslims identified a close association between religion and the dominant discourse of sexual morality, particularly how sex outside of marriage is positioned as immoral and associated with sinfulness (Bennett, 2007; Parker, 2009; 2014; Smith-Hefner, 2006). In Bennett's (2007) and Smith-Hefner's (2006) studies, the participants' dialogues about sex were dominated by religious terms such as "zina" (adultery) and "grave sin”. Parker's $(2009 ; 2014)$ studies among young Indonesian Muslims in Minangkabau identified a lack of resistance to this discourse of religious sexual morality, in the way that Indonesian youth themselves "give their consent to the authorities, displaying a striking commitment to social conservatism, local culture, and Islamic values" (2014, p. 
19). Similarly, previous research among Christian youth and church leaders in Surabaya (Wijaya Mulya, 2010) and in a Christian high school in Jakarta (Hoon, 2014) identified strong, widespread support for this dominant discourse in which sex outside (heterosexual) marriage is constituted as sinful and Christian young people are expected to maintain complete sexual abstinence. This article seeks to extend this area of enquiry by focusing on the discursive resources available among Indonesian Christian participants, particularly in relation to practices of resistance to the dominant discourse of sexual morality embedded in their processes of becoming sexual subjects.

Theoretically, this article is informed by a Foucauldian poststructuralist framework in its understanding of subjectivity, discourse, resistance and agency. This framework was chosen because it enables an examination of discursive-political aspects of the constitution of the selfwhich has been my interest in researching young people. Sexual subjectivity is understood as one's thoughts and emotions about one's sense of being sexual (Weedon, 1987), which is always constituted in relation to particular discourses (Foucault, 1982; Rabinow, 1984). Discourses offer individuals a range of ways-of-being in the world (i.e. subject positions) to be taken up (Weedon, 1987), so that individuals can construe their experiences from those positions. For instance, the dominant discourse of sexual morality offers a binary model of moral subjects (who maintain sexual abstinence) and immoral subjects (who engage in sex). It is through this binary that Indonesian young people may be positioned and understand themselves as sexual beings. In this way, Indonesian young people are not singular authors of their "identity" or understandings of themselves; rather, their subjective experiences reflect their engagement with wider discursive meanings circulating around them.

Since the discursive resources that give rise to subjectivities are ever-changing, the constitution of Indonesian young people as sexual subjects is not a one-off phenomenon but a continuous process. This continuous process of becoming is important as it enables possibilities for resistance. For example, the subject may draw on alternative discourses and exercise agentic disruptions to the dominant discourse of sexual morality by cultivating new forms of subjectivity (Foucault, 1985). As opposed to the common misunderstanding that Foucault's theorisation of the subject invalidates individuals' agency (Caldwell, 2007), the subject in this article is understood as agentic, not because of independent choices they make, but because of their capacity to go beyond the dominant discourse and develop new meanings (B. Davies, 1991) by which they understand themselves as sexual subjects. To resist the dominant discourse of sexual morality involves drawing on alternative discourses to challenge sets of meanings that have both enabled and constrained Indonesian youth in understanding themselves as sexual and taking action in their world.

\section{Research Methods}

The narratives presented here belong to 22 Indonesian Christians aged 16-24 years old whom I interviewed in 2013 as part of my research on young Indonesian Christians' sexual subjectivities. As I am seeking to explore various contextual and discursive resources within this context, Christians in this study are defined in a broad sense, which includes Protestants, Catholics, and also those who had a Christian background but no longer identify themselves as Christians. Most participants were college students (8 participants), high school students (6 participants) or in employment (5 participants). Others included a postgraduate student, an NGO activist, and a freelance journalist. Two participants identified as lesbian, four 
as gay, one as bisexual, fourteen as heterosexual, and one as asexual. Twelve participants identified as male, nine as female, and one identified as neither gender. No participants were married. In terms of ethnicity, twelve participants identified themselves as Javanese, seven as Chinese, one as Ambonese, one as Bataknese, and one as Sumbanese. Ten participants stated that they are/were a member of Pentecostal/charismatic churches, eight of Roman Catholic churches, and four of mainstream/ecumenical churches. Almost all participants are from urban middle-class families, except for four participants who lived in Christian shelters at the time of interview. After gaining ethics approval from the relevant authorities, I recruited participants through advertisements distributed to NGOs, churches, universities and community leaders in several major cities in Indonesia. The names of these cities are not disclosed to preserve confidentiality.

Data were produced through computer-mediated-communication (CMC) research methods - namely, semi-structured online interviews and autobiographical writing. CMC research methods were chosen because they offer advantages such as (1) increasing psychological comfort and security in studies on sensitive topics (McCoyd \& Kerson, 2006), (2) providing a more reflective temporal-spatial quality than face-to-face interviews, and therefore fostering a more equal and collaborative research relationship (James, 2016), and (3) giving a range of practical advantages (Mann \& Stewart, 2000) such as reaching participants in different geographical locations simultaneously. During the recruitment, ten participants wanted to see the researcher in person before agreeing to participate. Twelve participants signed and returned the consent form electronically (the researcher did not meet them at all). For these twelve participants, the researcher carefully and reflexively built rapport and trust via CMC research methods in the early phase of data collection, such as by revealing the researcher's own (struggle with his) Christian background and his openness to unique and different stories. Each participant engaged in 10-20 email exchanges over 4-12 weeks and one session of instant messenger chat (e.g. MSN Messenger, Yahoo Messenger or the chat feature on Skype), where the researcher was able to seek further clarification about particular answers. All interviews were conducted in participants' first language (Indonesian). I translated the narratives presented here into English. All names that refer to participants in this article are pseudonyms.

In examining participants' narratives I initially demonstrate how the dominant discourse of sexual morality has enabled and constrained these young people to understand themselves as sexual subjects. Subsequently, I explore participants' alternative subject positions from which they were able to contest the taken-for-granted meanings offered by the dominant discourse of sexual morality. I utilise Foucault's (1985) notion of ethics to examine these participants' subjectivities. Differing from discourses of morality where strict universal codes or authorities determine what is permitted and forbidden, in a discourse of ethics the subject is responsible for cultivating their own interpretation of right and wrong through self-reflection. This interpretation means that sexual enjoyment and restriction are more negotiable, and are not merely an act of mechanistic obedience.

\section{The Constitution of Sexual Subjectivities through the Dominant Discourse of Sexual Morality}

One participant who exemplified the binary of moral/immoral positions in the constitution of her sexual subjectivity is Yuyun. She was 16 years old at the time of our interview and 
studying in Year 11. She identified herself as heterosexual. Yuyun divides her life into two episodes, before and after Year 8. Before Year 8 she viewed herself as a good girl, a churchgoer, a virgin, who was obedient to her parents. After Year 8 she describes herself as someone who is "sinful", "useless" and "far from God". Her story below demonstrates how her sense of being sexual has been constituted through the dominant discourse of sexual morality:

My mum has taught me about Christianity since I was very young. We went to church, read the Bible, and learned to know God. But now everything has changed. It all started when I was in Year 8 (age 13). My boyfriend asked me to make love with him. I actually didn't want to, because I didn't want to lose my virginity. But then I abandoned everything because I really loved him. He is a liar and a deceiver. After we did it, a few days later he left me, and married another girl whom he had impregnated. I was really angry and sad. All I have has gone. I feel like my life has no meaning and myself no value. So I make friends with the devil and sin. At my home there is no love, no peace. I just want to hang out with my friends. I confront my parents, smoke, drink alcohol, and engage in free sex. I actually feel ashamed. Like a prostitute, I did it repeatedly. I am like a wild kid. My life is useless.

In drawing on the dominant discourse of sexual morality there appear to be only two subject positions that are thinkable for Yuyun - namely, being a moral virgin or an immoral prostitute. Since she can never again be an innocent virgin, taking up the moral position is unattainable and unrealistic in her current situation. Reading her text, it also appears to be challenging for her to stop socialising with her friends and just stay home where "there is no love, no peace". The moral standards Yuyun understands require her to reject all the "sinful" pleasures she has been enjoying such as alcohol, cigarettes and sex. Thus, the "only" option for Yuyun is to take up the immoral position. Given that the moral position is virtually unattainable for her now, she did not see any reason not to follow the immoral path and ignore moral values, or in her words, be "like a wild kid".

In contrast to Yuyun's story, other participants took up the moral subject position, such as through a narrative of repentance. Juwanto (18, high school student, male, heterosexual), for example, narrated his past as dark, sinful and immoral, but after he found God, he repented and left his past sins behind completely or is at least in a constant struggle with those sins:

After that [meeting God] I am changed. No more porn, masturbation, drinking, and smoking. I battle these sins. I fight them. Desires for those still haven't gone, it is a process, but I believe they can go.

Contrasting Yuyun's narrative with Juwanto's, it appears that a discourse of gender asymmetry has played a role in their positioning in the moral/immoral binary. Young women tend to be constituted or understand their engagement in sex as "immoral". Young men although their engagement in sex is also considered immoral - appear to have more leeway to take up the moral position by drawing on the notion of repentance. Unlike Yuyun, who found it "difficult to repent", Juwanto said that he "repented every time (he) fell"/engaged in sinful sexual acts such as masturbation and pornography, and therefore, maintained his position as a moral subject. I am cognizant that attributing the differences in participants' meaning-giving practice to the binary of male/female as such might limit possibilities for a more complex/multidimensional analysis, but previous international and Indonesian studies have reported similar findings in which gender continues to shape the bifurcation of meanings given to one's sexual experiences (Bennett, 2005; Carpenter, 2002; 2005; Holland, Ramazanoglu, Sharpe, \& Thomson, 2000; Platt, 2012; Tsui \& Nicoladis, 2004): young women's sexual activities (outside marriage) are associated with shame and guilt, while for young 
men they are associated with pride and joy. Although the theme of repentance is relatively common in Christian teachings, the notion of repentance from sexual "sins" is not always equally available to men and women. The perceived "irreversibility" of female virginity loss (Carpenter, 2005) or the notion of women being "damaged goods" once they lose their virginity has limited the possibilities for women to occupy the moral subject position. Van Nieuwkerk's $(2003 ; 2008)$ studies in Egypt, for example, indicated that the dominant narrative of repentance for "immoral" Muslim women generally involves a dramatic onceand-for-all change in lifestyle, including adopting the hijab.

Male participants in this study also show that occupying the moral position - although preferable - is not always pleasant and guilt-free. To maintain the moral position (i.e. to continuously align oneself with the religious moral standard of complete sexual abstinence) requires a constant nullification and suppression of sexual desires. For some participants, it is a difficult and endless struggle, loaded with feelings of guilt. Daniel, for instance, describes his experience:

I always feel regretful every time I fall [into sexual sin]. I feel like the problems in my family, like my mother's illness or her working in another city, are because I am naughty and sinful. It is not a punishment from God, but it's because I've left God. I asked God: "If you bring back my mom, I will stop masturbating. If needed, I'll chop my hands off”. I once masturbated and cried at the same time (Daniel, 17, high school student, male, heterosexual).

Drawing on the view that God is omniscient and all-knowing, Daniel cultivates a self-surveilling subjectivity that continuously monitors his own sexual morality. Feelings of guilt and regret are inescapable once he transgresses sexual moral standards, particularly when coupled with the understanding that sin brings negative consequences to one's life. For Daniel, these consequences are his mother's illness and his mother working in another city. To take up the moral subject position offered by the discourse of sexual morality, Daniel is required to abolish his sexual desire (until marriage, when it is deemed acceptable).

These narratives illustrate the powerful role that the dominant discourse of sexual morality can play in the constitution of Indonesian Christian young people's sexual subjectivities. To some extent, this discourse has restricted the possibility of young people taking up alternative subject positions beyond the moral/immoral binary. Positioning oneself as religious, moral and sexually active, for instance, is virtually unthinkable in this way of understanding young people as sexual subjects. It is difficult for young people to occupy subject positions from which they can negotiate enjoyment and self-limitation, pleasure and responsibility, and desire and control. Further, same-sex sexual practice is constituted as immoral since same-sex marriage in Indonesia is not legally recognised and is generally condemned by mainstream religious communities (e.g. Mutiara, 2015).

\section{Contesting the Dominant Discourse of Sexual Morality}

In this section I investigate how participants occupy alternative subject positions from which they can resist, reinterpret and even abandon the constitution of young people's sexual practice as a moral problem. Using Foucault's (1985) comparison of morality and ethics, I will discuss three ways participants position themselves and/or are positioned as ethical sexual subjects. The first is casting off religion altogether, in which the strongest foundation of sexual morality is ousted so that moral/immoral subject positions become increasingly irrelevant. The second is reinterpreting religious morality, where the prescriptive character of 
code-oriented morality is rejected and authoritative moral codes are replaced by a personal interpretation of religious doctrines. The last is practising double morality, in which one's relation with moral codes allows for betrayal under certain circumstances.

\section{Casting off religion altogether}

The first example of resistance to the dominant discourse of sexual morality can be seen in Susanti's (22, college student, female, lesbian) way of being a sexual subject - that is, through her disengagement from Christian faith. She described herself as growing up in a devout Protestant family. She had been involved extensively in her church and read many Christian books since her childhood, but at university she started to question her faith and eventually decided she no longer believed in God. This is an exceptionally subversive decision, considering that atheism is not a subjectivity recognised by the Indonesian government (Schäfer, 2016; Wieringa, 2000) and has long been associated with the Indonesian Communist Party, which was declared to be a state enemy and was violently attacked by the Soeharto regime (1966-98).

I once told my parents I am a lesbian. We had a big quarrel, and they told me I will go to hell. I felt guilty and condemned at that time because I believed that being a lesbian is wrong and sinful. I tried harder to obey God, prayed more, read the Bible more, and got involved in church activities, so that I could be straight. I went to counselling sessions, with both psychiatrist and pastor, but I still failed (to be straight). I then read writings that said the Bible is historically invalid, such as articles in the ex-christian.net forum and also studies that show how Christian doctrines about LGBT are full of hatred. The climax was when my close friend told me that I will go to hell for being lesbian. I was really angry and had had enough of Christianity and of God Himself. So I decided to be an atheist.

I used to believe that sex is only for married people, and masturbation is a sin. After I became an atheist, my mind was opened. Sex is a biological need, not a sin. The concept of sin is like this: God will punish humans if they do something wrong; thus humans will not engage in wrongdoing any more because they are afraid of punishment. If there is no hell, will they still do the right thing? Sex is a biological need; there should be no problem with it. Some people can restrain it, some people can't. Who said there were no genital diseases in the medieval ages when Christianity was thriving all over Europe? One of the women of King Henry VIII of England got syphilis and so did the King. The disease is purely biological, not a punishment from God.

I believe morality is created by humans so that we can live comfortably. I myself do not steal or kill people because I clearly know it hurts people. I don't want to be hurt, so I don't hurt people. People engage in crime not because they don't have religion, but because they have the opportunity and they decide to do it.

Susanti's narrative shows how her sexuality has been subjected to various moralising mechanisms. Her parents, her pastor, her psychiatrist, and even her close friend attempted to normalise her into becoming a sexually moral subject, which in her social context meant being abstinent and heterosexual. Their moral messages (in)formed Susanti's ways of giving meaning to her sexual self, and led her to feel guilty. She then tried to fix her "moral" problem by performing religious rituals such as praying, reading the Bible, and being involved in church activities. All of the invitations, pressures and condemnations gradually fuelled Susanti's desire to uproot herself from her Christian faith.

By drawing on the resources to which she had access (e.g. atheist forums, criticisms of the Bible from history and sexuality studies), Susanti was able to abandon her Christian faith and take up an atheist subject position. This change became the milestone in her 
understanding of morality: "After I became an atheist, my mind was opened". It enabled her to leave the binary logic of morality, such as sinful/holy, punishment/reward, heaven/ hell, and replace these with the ethical principle of reciprocity: "I don't want to be hurt, so I don't hurt people". It became possible for her to de-sacralise morality - that is, from divine instruction to human invention: "I believe morality is created by humans so that we can live comfortably". Atheism provided the means for Susanti to reject the association of religion with sexual morality (e.g. her awareness of STIs in Medieval Christendom), and of religion with morality in general: "People engage in crime not because they don't have religion", "I myself [an atheist] do not steal or kill people". She moved from the understanding of sex as a moral problem to a biological explanation: "Sex is a biological need, not a sin". Once the strongest foundation of sexual morality in her life - her Christian faith - was ousted, more discursive spaces opened up for her to cultivate an ethical, sexual self. She was able to reflect, negotiate and redefine her understandings of sexuality, instead of obediently following what authorities dictated. Here, the binary positioning of moral/immoral young people became irrelevant when her concept of sexuality was no longer constituted through the dominant discourse of sexual morality.

Susanti's narrative reveals an alternative subject position occupied by a young Indonesian Christian, one beyond the moral/immoral positions offered by the dominant discourse of sexual morality. Through a radical change from Christian faith to atheism, she was able to resist the constitution of young people's sexual practice as primarily a moral problem. In this way, the whole set of meanings around morality that was rooted in her religious beliefs became more open to redefinition. Specifically, the universalising, prescriptive and moralistic approach to sexuality that was normalised through religious authorities was replaced by a more personal and negotiated ethical approach to sexuality.

Susanti's atheist and lesbian subjectivity represents a double and radical deviation from normative ways of being an Indonesian youth. Previous international studies have also shown that renouncing one's religious upbringing as described in Susanti's narrative is relatively uncommon among religious LGBT+ people (e.g. Gross \& Yip, 2010; Radojcic, 2016; van Klinken, 2015; Yip, 1997a; 1997b; 2005). As these studies have identified, staying within a faith and reinterpreting religious morality tends to be a preferable option for religious LGBT+ people. Accordingly, among participants in this study only Susanti underwent such a radical change in religious beliefs.

\section{Reinterpreting religious morality}

The second example of resistance to the dominant discourse of sexual morality is evident in the constitution of 24-year-old Anto's (NGO activist, male, gay) sexual subjectivity. Drawing on alternative discursive resources, he rejected the positioning of young people as moral sexual subjects by reinterpreting religious moral codes. He reinvented his "own" sexual ethics based on his understanding of the Bible and the all-loving character of God (Gross \& Yip, 2010), which were quite different from what his church prescribed. Anto had just completed his university education and was actively involved in an LGBT+ NGO at the time I interviewed him. As an activist he focused on promoting the health of LGBT+ people, mainly by encouraging them to come out and to use condoms. He has proudly come out as gay and does not support sexual abstinence. Anto goes to a Pentecostal mega-church known for its conservative theology, charismatic leadership, strong evangelism and miraculous 
healings. He describes this church as "very conventional in terms of sexuality", where it is "a taboo to talk about sex", and "the idea of procreation is dominant". Anto is also actively involved in evangelical activities in his church (i.e. telling people about Jesus). He explained that he had no problem reconciling his faith and his sexuality:

The meaning of Christianity is so deep for me. I found comfort in this religion. Regardless of what the pastors preached, when I read the Word of God, immersed myself in the meaning of it, I felt how great is the love He gives. It convinced me that He accepts me just the way I am. I really like Jesus' teachings about love, how He taught me to call Him friend. For me, the closeness between friends is much more meaningful than servant-master. That is why I always believe God loves me for what I am ... Jesus is a very close friend of mine. When I need to talk heart-to-heart, I just close my eyes, and I tell Him my experiences. He has never disappointed me. When I had problems and did not know what to do, I just prayed, and it calmed me down. I know I can always rely on Him.

Anto's narrative on Christian faith is characterised by a deep personal relationship with God and an understanding of the loving character of God. He sees God as an intimate figure with whom he can always talk as a friend. This personal relationship has provided Anto with a foundation on which to build his "own" understanding of God and Christianity, which does not necessarily correspond to what pastors teach from the pulpit. By doing this, Anto is able to de-sacralise some aspects of the Christian moral code and replace them with his "own" versions. For instance, while his church condemns gay and lesbian young people and those who engage in sexual activities, Anto dismisses this condemnation by believing that "God accepts me" and "God loves me for what I am". By appealing to the loving "nature" of God, Anto is able to refuse the immoral subject position offered by the dominant discourse of sexual morality.

Drawing on the notion of God's love to oppose or resist church teachings - as Anto did has been identified as relatively common in previous international studies. Yip's work among LGBT+ religious young people in the UK (Page \& Yip, 2012; Yip, 1997a; 1997b; 2002; 2005; Yip \& Page, 2013) revealed similar ways of reinterpreting heteronormative religious teachings that condemn same-sex and other sexualities. Many of Yip's Christian participants separated church teaching from the "true" Christian faith. For example, they argued that the church has been historically incorrect in the past, as it previously supported slavery (Yip, 1997a). In this way, biblical interpretive authority is relocated from religious leaders to the personal realm of believers (Yip, 2002). Sacred texts are then used as a foundation to de-centre institutional authority and democratise religious beliefs and values (Page \& Yip, 2012; Yip \& Page, 2013).

In the Indonesian context, previous studies have reported similar reinterpretations within progressive Muslim communities (Bennett, 2007; Smith-Hefner, 2009; Wieringa, 2010). These scholars have documented how Islamic traditions that generally teach strict sexual-abstinence-until-marriage can provide resources for different interpretations around sexual morality. Bennett (2007), for instance, identified how some progressive Muslim scholars in Indonesia have supported a more comprehensive approach to teaching sexuality according to their interpretation of the Islamic sacred texts. Similarly, Wieringa (2010) drew attention to a progressive Muslim scholar, Professor Musdah Mulia, whose understanding of Islamic sexual morality acknowledged sexual diversity beyond heterosexuality. These studies show the possibility of various (re)interpretations in reading religious texts to challenge the discourse of sexual morality currently dominant in Indonesia. 
What is unique about Anto's way of contesting religious sexual morality, compared to the findings of previous studies, is his relational and emotional source of critique. Most participants cited in earlier studies contested the dominant discourse of sexual morality by using hermeneutical arguments, such as pointing to incorrect interpretations of religious texts. In contrast, Anto's narrative shows that resistance to church teachings does not have to rely on the logic of arguments. Instead, it can be based on an individual's experience of their personal and intimate relationship with God - or what Yip (2010, p. 40) called "a sexual theology and ethics that ... prioritises embodiment and experience" rather than sacred texts. The sense of trust Anto developed in his personal relationship with God provided him with the confidence to depart significantly from common Christian doctrines. For example, the notion of heaven and hell - which is usually seen as the reason behind some Christians' moral practice - is very different in Anto's view:

I never thought that non-Christians would end up in hell. The concepts of heaven and hell have long gone from my head. What's in my head is that the role of religion is to make people comfortable in this world, without being occupied by thoughts that they will go to heaven or hell. I come to Him not because I want to end up in heaven, but because I miss Him. It's like a desire to "visit" a close friend. Regarding sex, my understandings came from (academic) journals, lecturers and so on. A human is basically not just a social being, but also a sexual being. This means that sex is a basic human need. Since it is a basic need, it needs to be met, right?

By drawing on his personal relationship with God, Anto was able to refuse the transactional character of traditional Christian morality, in which Christians obey God because of the promise of going to heaven. Anto's religious morality is relational ("I come to Him ... because I miss Him") and worldly ("the role of religion is to make people comfortable in this world"). His sense of morality is not focused on the distinction between what is right/wrong and holy/sinful according to Christian doctrines; he considers many other views and sources, such as scholarly work. In this way, there are more discursive spaces for Anto to develop his own sexual ethics, which apparently draw upon the notion that "sex is a basic human need", one that "needs to be met".

Anto's narrative represents another way in which Indonesian young people take up alternative subject positions beyond those offered by the dominant discourse of sexual morality. Unlike Susanti, who completely rejected her religious beliefs, Anto challenged specific aspects of religious morality that are prescriptive and universalising. He radically reinterpreted Christian moral teachings by drawing on his personal relationship with God as the foundation for his sense of right and wrong. By giving meaning to his sexual self through ideas such as "God is love" and "sex is a human need", Anto is able to resist the narrow positioning of Indonesian young people as either moral or immoral sexual subjects.

So far in this section I have presented narratives of resistance to the dominant discourse of sexual morality from Susanti who abandoned her Christian faith and Anto who reinterpreted traditional Christian doctrines. Such forms of resistance have opened up possibilities for aligning their sexual identities and practices with their religious beliefs. Similarly, in some previous studies (e.g. Gross \& Yip, 2010; Mahaffy, 1996; Yip, 1997a; 1997b; 2005; Yip \& Page, 2013), LGBT+ participants are reported as reinterpreting their religious-moral values to resolve the gap or "dissonance" between their beliefs and sexual practice or identity. However, other participants in this study did not necessarily try to achieve such coherency; their narratives demonstrate how resistance to the dominant discourse of sexual morality does not have to be consistent, coherent or without contradiction. 


\section{Practising double moralities}

A third way Indonesian young people gave new meanings to their sexual self beyond those offered by the dominant discourse of morality is akin to Heywood's (2015) notion of doppia morale or double morality. Heywood (2015, p. 201) defines double morality as "a capacity to subscribe to a rule or injunction in such a way as to allow for the possibility of its betrayal under certain circumstances". Using examples from Italian public figures, Heywood identifies how the issue of morality is often not about a failure to live up to a moral code consistently, but about a failure to do so in a certain context such as public or private spheres. The marital infidelities of former Italian Prime Minister Berlusconi, for example, were "indulged" (2015, p. 207) by his wife until the affairs were exposed in the national media. Once the inconsistencies between moral beliefs and actions are exposed (i.e. when the private becomes public), personal judgment and individual values previously permitted to supersede moral conventions within a person's private life cease to be relevant. Different from double standards (where different moral standards are applied to two comparable contexts), the concept of double morality recognises that the contexts are not always comparable. Doppia morale allows different parts of a person to relate to the same moral codes differently - that is, by both subscribing to and betraying them. In this way, it opens up the possibility that young Indonesian Christians' ethical sexual selves might exist without first abolishing or reinterpreting the moral code of (hetero)sexual abstinence.

Urip, a 24-year-old heterosexual male who works as a salesperson, is one example. Coming from a "nice and warm Catholic family", he is known by his family and neighbours as a "good boy". He describes himself as "a devoted person in terms of religion" - that is, he prays and goes to church regularly. Here, his public performance of religiosity seemingly aligns with the category of a moral young person, but in his private life Urip has secretly engaged in sexual activities, or what he calls his "other side". This started when he watched pornography with other children in his neighbourhood when he was seven years old. Every time one of their houses was empty, the children gathered and watched pornographic videos. Since then he has masturbated, and since completing high school he has engaged in sex with his girlfriends.

In his talk about himself as a sexual being, Urip gives meaning to his sexual self in a way that is both compliant and resistant to the dominant discourse of sexual morality, resembling Heywood's notion of double morality. Unlike Susanti and Anto, Urip did not challenge or reinterpret the morality taught by his church. He completely agrees with the church's sexual morality that considers sex outside marriage to be sinful. He explained:

The church definitely forbids free sex [sex outside marriage]. I personally believe that before God each individual is responsible for such conduct. I am not sure what the punishment is, but I know certainly that it is sinful.

While in terms of religion I am very devoted, in terms of sex I think it is each individual's business. For me, I don't think it is dirty or sinful... I have no specific rules in making love, just put it simply like this: whatever we do, as long as we both feel comfortable and there's no coercion, we feel free to do it.

Bennett's (2005) study among young Muslim girls in Lombok has identified how Indonesian young people have negotiated the imposition of sexual moral codes by maintaining the performance of a moral self in public while transgressing those codes in their private lives. Similarly, Urip differentiated his (public) religious self who supports the moral code of sexual abstinence, from his (private) sexual self or his "other side" who 
"do[es]n't think it (sex) is dirty or sinful", and did not express any concern or need to reconcile the two spheres. Urip positioned his public religious self and his private sexual self - in Heywood's (2015) words - as incomparable contexts. The private sexual sphere is "each individual's business", where personal judgment or individual value is allowed to replace moral impositions. For Urip, it is the consensuality of the sexual relationship. By practising double morality, Urip is able to take up the moral subject position (in his public life), and simultaneously transgress the moral code of abstinence (in his private life).

Extending Bennett's (2005) and Heywood's (2015) valuable contribution of conceptualising the public/private spheres as a crucial analytical axis, my examination of Urip's narrative shows that this binary might not be easily and straightforwardly applied in analysing young people's subjectivities. There are complexities in Urip's story that indicate a blurred line between his public religious self and his private sexual self.

I feel really grateful and glad to be born in a family that can guide me to know and have faith in Catholicism. I really believe that Catholicism is the way and the guide for me to the truth - that is, to God. I know that I still have much to learn about this faith, but I will always learn and learn and learn :-)

In my relation with myself, actually there is a guilty feeling after every time I make love. I'm not sure to whom I direct my guilty feeling ... perhaps to my parents because they know me as a "good" child, but I have that "other side" ... when I feel like I "want to do it", it will dominate my thoughts (oh gosh I feel embarrassed $\mathrm{x} \_\mathrm{x}$ ) but that is very rarely... Every time I want sex I am always, like, "defeated" by my desire to make love, then afterwards I feel guilty.

First of all, rendering Urip's religious devotion as a public "performance" (which is aimed at creating an image of sexual purity to conceal his transgressive sexual self) might ignore or even deny the statement that he "really believe[s] that Catholicism is the way and the guide for (him) to the truth". Considering his active involvement in church activities, there is a possibility that - rather than a "performance" - his religious beliefs and practices might be performative (Butler, 1990), through which his sense of self is constituted. Catholicism might be something personal, an important part of Urip's private practices of self-relation.

Secondly, although Urip said that youth sex is not "dirty or sinful", he was still "feeling guilty after every time (he) made love". In a way he might still apply the moral code from his public religious life to his private sexual life. Put another way, he might find these two spheres still comparable to some degree. In the constitution of Urip's sexual subjectivity, there are complex and contradictory engagements with the dominant discourse of sexual morality that may involve multiple and intertwined relationships between his public and private lives.

Urip's narrative demonstrates how an alternative subject position beyond the binary of moral/immoral young people can be occupied - that is, by practising a double morality. Drawing on various alternative discourses, Urip inhabits a subject position from which he can relate to the moral code of sexual abstinence in a way that allows for transgressions under certain circumstances, such as in his private life. He showed how subjectivity need not be unified and coherent, but instead may be fractured and conflicting, both between and within public and private spheres. Urip's narrative shows that one's "good" side and one's "other side" might co-exist and be intertwined with each other. He simultaneously felt glad and embarrassed, sinful and grateful, transgressive and ethical. By conceptualising Urip's story in this way, I have also provided an empirical narrative that gives expression to some contemporary theorisations of the self as multiple and contradictory in various fields, such 
as Ewing's (1990) work in cultural and religious studies, Schielke's $(2008 ; 2009)$ research in anthropology and morality, and Rudy's (2007) queer theological analyses. For instance, Rudy (2007, p. 43) has noted:

What I need is a theory of subjectivity that would allow me to be two contradictory things at the same time, that would allow me to say "I believe" and "I don't" in a way that does not require coherent explanation. I need a theory that will allow me to be fragmented, not as a temporary stopgap measure until I figure out where I will end up, but a theory that will allow me to understand myself as divided, now and forever. I need a model that does not obligate me to be only one, unified person, that does not rest its idea of subjectivity on Enlightenment individuality, that sees fragmentation as a natural state and not one to be worked through.

\section{Conclusion}

The present study has examined the interplay between religion, morality and sexual subjectivity in the context of contemporary Indonesian Christian young people. Specifically, it contributes to the theorisation of the (re)production of Christian young people as sexual subjects through the dominant discourse of sexual morality in Indonesia. I have presented empirical narratives of how this discourse has been both drawn upon and contested in an Indonesian Christian context. I have argued that while drawing on the dominant discourse of sexual morality can enable young people to be positioned as moral/immoral sexual subjects, it can also limit the possibilities for giving meaning to their sexual selves beyond this binary. I have revealed how the possibility of becoming an ethical sexual subject who negotiates the various considerations of engaging in sex, instead of following the moral code of abstinence, is significantly constrained. Conversely, this article also provides evidence that the dominant discourse of sexual morality can be contested in the constitution of Indonesian Christian young people as sexual subjects. It has identified three alternative ways in which Indonesian young people have contested binary moral versus immoral positioning. Some young Indonesian Christians have abandoned their faith altogether, while others have reinterpreted the moralistic parts of their religious beliefs or practised a double morality in their private and public lives. This finding suggests that the power of the dominant discourse of sexual morality in Indonesia is not monolithic or uncontested - it has cracks and fissures - and Indonesian youth are not docile subjects. In the constitution of sexual subjectivities they are capable of exercising agency, enabled by alternative discourses that they have access to. By presenting these possibilities for resistance to the dominant discourse, I have offered a new interpretation of young people's ways of seeing and being a sexual subject, beyond those offered by the dominant discourse of sexual morality in Indonesia. In so doing I have sought to contribute to, and continue, Foucault's (1985) project of promoting the creation and proliferation of alternative ways of being in the world.

\section{Acknowledgments}

This work was made possible by the Indonesian Directorate General of Higher Education under the Beasiswa Luar Negeri (BLN) scholarship scheme.

\section{Disclosure statement}

No potential conflict of interest was reported by the author. 


\section{References}

Bennett, L. R. (2005). Patterns of resistance and transgression in Eastern Indonesia: Single women's practices of clandestine courtship and cohabitation. Culture, Health \& Sexuality, 7(2), 101-112. doi:10.1080/13691050412331291397

Bennett, L. R. (2007). Zina and the enigma of sex education for Indonesian Muslim youth. Sex Education, 7(4), 371-386. doi:10.1080/14681810701635970

Boellstorff, T. (2005). Between religion and desire: Being Muslim and gay in Indonesia. American Anthropologist, 107(4), 575-585. doi:10.1525/aa.2005.107.4.575

Butler, J. (1990). Gender trouble: Feminism and the subversion of identity. New York: Routledge.

Caldwell, R. (2007). Agency and change: Re-evaluating Foucault's legacy. Organization, 14(6), 769791. doi:10.1177/1350508407082262

Carpenter, L. M. (2002). Gender and the meaning and experience of virginity loss in the contemporary United States. Gender \& Society, 16(3), 345-365. doi:10.1177/0891243202016003005

Carpenter, L. M. (2005). Virginity lost: An intimate portrait of first sexual experiences. New York: New York University Press.

Davies, B. (1991). The concept of agency: A feminist poststructuralist analysis. Social Analysis, 30, 42-53. Retrieved from http://www.jstor.org/stable/23164525

Davies, S. G. (2011). Gender diversity in Indonesia: Sexuality, Islam and queer selves. London: Routledge.

Davies, S. G. (2015). Surveiling sexuality in Indonesia. In L. R. Bennett \& S. G. Davies (Eds.), Sex and sexualities in contemporary Indonesia: Sexual politics, health, diversity and representations (pp. 29-50). New York: Routledge.

Ewing, K. P. (1990). The illusion of wholeness: Culture, self and the experience of inconsistency. Ethos, 18(3), 251-278. doi:10.1525/eth.1990.18.3.02a00020

Foucault, M. (1978). The history of sexuality, vol. 1: The will to knowledge (Trans. R. Hurley). New York: Pantheon Books.

Foucault, M. (1982). The subject and power. Critical inquiry, 8(4), 777-795. Retrieved from http:// www.jstor.org/stable/1343197

Foucault, M. (1985). The history of sexuality, vol. 2: The use of pleasure (Trans. R. Hurley). New York: Pantheon Books.

Gross, M., \& Yip, A. K. T. (2010). Living spirituality and sexuality: A comparison of lesbian, gay and bisexual Christians in France and Britain. Social Compass, 57(1), 40-59. doi:10.1177/0037768609355535

Haq, A. (2016, 27 April). Digerebek polisi, sepasang kekasih hanya berpakaian dalam di kamar kos (Raided by the police, a couple only wore underwear in a rented room). Kompas. Retrieved from http://regional.kompas.com/read/2016/04/27/22110851/Digerebek.Polisi.Sepasang.Kekasih. Hanya.Berpakaian.Dalam.di.Kamar.Kos

Harding, C. (2008). The influence of the "decadent West": Discourses of the mass media on youth sexuality in Indonesia. Intersections: Gender and Sexuality in Asia and the Pacific, 18. Retrieved from http://intersections.anu.edu.au/issue18/harding.htm

Heywood, P. (2015). Freedom in the code: The anthropology of (double) morality. Anthropological Theory, 15(2), 200-217. doi:10.1177/1463499614568498

Holland, J., Ramazanoglu, C., Sharpe, S., \& Thomson, R. (2000). Deconstructing virginity - young people's accounts of first sex. Sexual and Relationship Therapy, 15(3), 221-232. doi:10.1080/14681990050109827

Hoon, C.-Y. (2014). God and discipline: Religious education and character building in a Christian school in Jakarta. South East Asia Research, 22(4), 505-524. doi:10.5367/sear.2014.0232

James, N. (2016). Using email interviews in qualitative educational research: Creating space to think and time to talk. International Journal of Qualitative Studies in Education, 29(2), 150-163. doi:10 $.1080 / 09518398.2015 .1017848$

Kailani, N. (2012). Forum Lingkar Pena and Muslim youth in contemporary Indonesia. RIMA: Review of Indonesian and Malaysian Affairs, 46(1), 33. Retrieved from http://search.informit.com. au/documentSummary; $\mathrm{dn}=984332214396280 ;$ res=IELIND

Lim, M. (2013). The internet and everyday life in Indonesia: New moral panics? Bijdragen tot de Taal-, Land-en Volkenkunde, 169, 133-147. doi:10.1163/22134379-12340008 
Mahaffy, K. A. (1996). Cognitive dissonance and its resolution: A study of lesbian Christians. Journal for the Scientific Study of Religion, 35(4), 392-402. doi:10.2307/1386414

Mann, C., \& Stewart, F. (2000). Internet communication and qualitative research: A handbook for researching online. London: SAGE.

McCoyd, J. L. M., \& Kerson, T. S. (2006). Conducting intensive interviews using email: A serendipitous comparative opportunity. Qualitative Social Work, 5(3), 389-406. doi:10.1177/1473325006067367

Mutiara, P. (2015, 4 March). Hukuman mati pelaku sodomi anak (Death sentence for child sodomy). Media Indonesia. Retrieved from http://www.mediaindonesia.com/mipagi/read/8910/HukumMati-Pelaku-Sodomi-Anak/2015/03/04

Natahadibrata, N. (2013, 5 December). Ministry halts condom program. The Jakarta Post. Retrieved from http://www.thejakartapost.com/news/2013/12/05/ministry-halts-condom-program.html

Page, S.-J., \& Yip, A. K.-T. (2012). Religious young adults recounting the past: Narrating sexual and religious cultures in school. Journal of Beliefs \& Values, 33(3), 405-415. doi:10.1080/13617672.2 012.732819

Parker, L. (2009). Religion, class and schooled sexuality among Minangkabau teenage girls. Bijdragen tot de Taal-, Land-en Volkenkunde, 165(1), 62-94. Retrieved from http://www.kitlv-journals.nl/ index.php/btlv

Parker, L. (2014). The moral panic about the socializing of young people in Minangkabau. Wacana, 15(1), 19-40. Retrieved from http://wacana.ui.ac.id/index.php/wjhi/article/viewFile/103/96

Platt, M. (2012). Married men behaving badly: Islam, gender and extramarital relationship in Eastern Indonesia. Intersections: Gender and Sexuality in Asia and the Pacific, 28. Retrieved from http:// intersections.anu.edu.au/issue28/platt.htm

Platt, M.W., Davies, S., \& Bennett, L. (2018). Contestations of gender, sexuality and morality in contemporary Indonesia. Asian Studies Review, 42(1). Advance online publication. doi:10.1080/ 10357823.2017 .1409698

Rabinow, P. (Ed.). (1984). The Foucault reader. New York: Pantheon Books.

Radojcic, N. (2016). Building a dignified identity: An ethnographic case study of LGBT Catholics. Journal of Homosexuality. Advance online publication. doi: 10.1080/00918369.2016.1151698

Rudy, K. (2007). Subjectivity and belief. In G. Loughlin (Ed.), Queer theology: Rethinking the western body (pp. 37-49). Malden, MA: Blackwell Publishing.

Schäfer, S. (2016). Forming "forbidden" identities online: Atheism in Indonesia. Austrian Journal of South-East Asian Studies, 9(2), 253-268. doi:10.14764/10.ASEAS-2016.2-5

Schielke, S. (2008). Policing ambiguity: Muslim saints-day festivals and the moral geography of public space in Egypt. American Ethnologist, 35(4), 539-552. doi:10.1111/j.1548-1425.2008.00097.x

Schielke, S. (2009). Being good in Ramadan: Ambivalence, fragmentation, and the moral self in the lives of young Egyptians. Journal of the Royal Anthropological Institute, 15(s1), S24-S40. doi:10.1111/j.1467-9655.2009.01540.x

Smith-Hefner, N. J. (2005). The new Muslim romance: Changing patterns of courtship and marriage among educated Javanese youth. Journal of Southeast Asian Studies, 36(3), 441-459. doi:10.1017/ S002246340500024X

Smith-Hefner, N. J. (2006). Reproducing respectability: Sex and sexuality among Muslim Javanese youth. Review of Indonesian and Malaysian Affairs, 40(1), 143-172. Retrieved from https://search. informit.com.au/documentSummary; $\mathrm{dn}=243252846988966$;res=IELAPA

Smith-Hefner, N. J. (2009). "Hypersexed" youth and the new Muslim sexology in Java, Indonesia. Review of Indonesian and Malaysian Affairs, 43(1), 209-244. Retrieved from https://search.informit. com.au/documentSummary;dn=277693838465109;res=IELAPA

Surya. (2016, 19 May). Ketika polisi mendadak razia pornografi di sekolah dan warnet (When the police inspect schools and internet cafes for pornography). TribunNews. Retrieved from http:// www.tribunnews.com/regional/2016/05/19/ketika-polisi-mendadak-razia-pornografi-di-sekolahdan-warnet

Tsui, L., \& Nicoladis, E. (2004). Losing it: Similarities and differences in first intercourse experiences of men and women. Canadian Journal of Human Sexuality, 13(2), 95-106. Retrieved from http:// search.proquest.com/health/docview/220819046?accountid=170128 
Undang-Undang Republik Indonesia Nomor 44 Tahun 2008 tentang Pornografi (Republic of Indonesia Law no. 44 year 2008 about pornography). (2008).

van Klinken, A. (2015). Queer love in a "Christian nation": Zambian gay men negotiating sexual and religious identities. Journal of the American Academy of Religion, 83(4), 947-964. doi:10.1093/ jaarel/lfv073

Van Nieuwkerk, K. (2003). On religion, gender, and performing: Female performers and repentance in Egypt. In T. Magrini (Ed.), Music and gender: Perspectives from the Mediterranean (pp. 267-286). Chicago: University of Chicago Press.

Van Nieuwkerk, K. (2008). "Repentant" artists in Egypt: Debating gender, performing arts and religion. Contemporary Islam, 2(3), 191-210. doi:10.1007/s11562-008-0061-z

van Wichelen, S. (2010). Religion, politics and gender in Indonesia: Disputing the Muslim body. New York: Routledge.

Webster, T. W. (2010). Pergaulan bebas and gendered youth culture in Yogyakarta, Indonesia. Unpublished doctoral dissertation. University of Western Australia, Perth. Retrieved from researchrepository. uwa.edu.au/files/3245809/Wright_Webster_Tracy_2010.pdf

Weedon, C. (1987). Feminist practice and poststructuralist theory. Oxford: Blackwell.

Wieringa, S. E. (2000). Communism and women's same-sex practises in post-Suharto Indonesia. Culture, Health \& Sexuality, 2(4), 441-457. doi:10.1080/13691050050174440

Wieringa, S. E. (2010). Gender variance in Asia: Discursive contestation and legal implications. Gender, Technology and Development, 14(2), 143-172. doi:10.1177/097185241001400202

Wijaya Mulya, T. (2010). Church youth sexuality in Surabaya: Teachings, attitudes, and behaviors. Anima Indonesian Psychological Journal, 25(3), 215-224. Retrieved from http://anima.ubaya.ac.id/ class/openpdf.php?file=1372231967.pdf

Yip, A. K.-T. (1997a). Attacking the attacker: Gay Christians talk back. British Journal of Sociology, 48(1), 113-127. doi:10.2307/591913

Yip, A. K.-T. (1997b). Dare to differ: Gay and lesbian Catholics' assessment of official Catholic positions on sexuality. Sociology of Religion, 58(2), 165-180. doi:10.2307/3711875

Yip, A. K.-T. (2002). The persistence of faith among non-heterosexual Christians: Evidence for the neosecularization thesis of religious transformation. Journal for the Scientific Study of Religion, 41(2), 199-212. doi:10.1111/1468-5906.00111

Yip, A. K.-T. (2005). Queering religious texts: An exploration of British non-heterosexual Christians' and Muslims' strategy of constructing sexuality-affirming hermeneutics. Sociology, 39(1), 47-65. doi: $10.1177 / 0038038505049000$

Yip, A. K.-T. (2010). Coming home from the wilderness: An overview of recent scholarly research on LGBTIQ religiosity/spirituality in the West. In K. Browne, S. R. Munt, \& A. K. T. Yip (Eds.), Queer spiritual spaces: Sexuality and sacred places (pp. 35-50). Farnham: Ashgate.

Yip, A. K.-T., \& Page, S.-J. (2013). Religious and sexual identities: A multi-faith exploration of young adults. Surrey: Ashgate Publishing. 

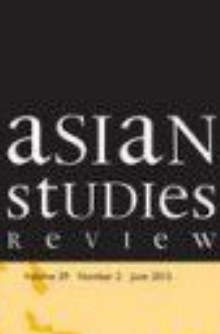

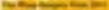

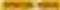

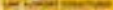

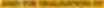

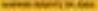

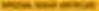

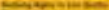

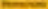

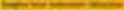

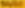

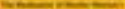

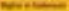

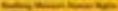

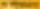

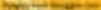

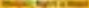

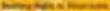

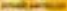

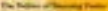

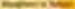

Hen 스. 
Journal

\title{
Asian Studies Review >
}

\author{
This journal
}

\section{Journal information}

Print ISSN: 1035-7823 Online ISSN: 1467-8403

4 issues per year

Asian Studies Review is currently noted in:

American History and Life

Bibliography of Asian Studies

CSA Worldwide Political Science Abstracts (Cambridge Scientific Abstracts)

EBSCOhost

El (Online) (Excerpta Indonesica)

Historical Abstracts

Humanities International Index

Information Service

International Bibliograpohy of the Social Sciences

OCLC

ProQuest

SCOPUS

Social Services Abstracts

Sociological Abstracts

Swets Information Services

Thomson Gale (Gale Group)

World Banking Abstracts

World Magazine Bank 
Asian Studies Association of Australia and our publisher Taylor \& Francis make every effort to ensure the accuracy of all the information (the "Content") contained in our publications. However, Asian Studies Association of Australia and our publisher Taylor \& Francis, our agents, and our licensors make no representations or warranties whatsoever as to the accuracy, completeness, or suitability for any purpose of the Content. Any opinions and views expressed in this publication are the opinions and views of the authors, and are not the views of or endorsed by Asian Studies Association of Australia and our publisher Taylor \& Francis. The accuracy of the Content should not be relied upon and should be independently verified with primary sources of information. Asian Studies Association of Australia and our publisher Taylor \& Francis shall not be liable for any losses, actions, claims, proceedings, demands, costs, expenses, damages, and other liabilities whatsoever or howsoever caused arising directly or indirectly in connection with, in relation to, or arising out of the use of the Content. Terms \& Conditions of access and use can be found at http://www.tandfonline.com/page/terms-andconditions .

\section{Publication history}

\section{Currently known as:}

Asian Studies Review (1990 - current)

\section{Formerly known as}

Asian Studies Association of Australia. Review (1977 - 1990)

Latest two full volumes

FREE to you for 14 days

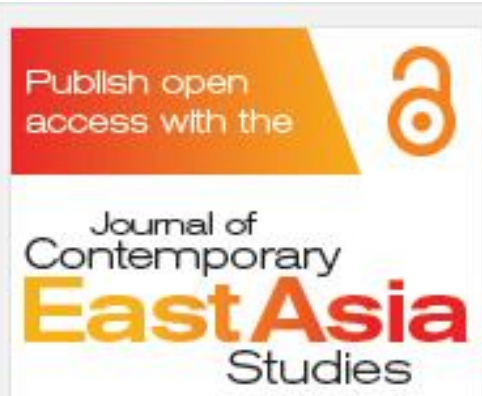


Routledge

\% Taylor \& Francis Group

Routledge Custom

Publishing

Create custom

textbooks with ease

Information for

Authors

Editors

Librarians

Societies

Help and info

Help

FAQS

Press releases

Contact us

Commercial services
Open access

Overview

Open journals

Open Select

Cogent OA

Connect with Taylor \& Francis

fⓘn

Youn

Copyright $(2017$ Informa UK Limited Privacy policy \& cookies Terms \& conditions

Accessibility

Registered in England \& Wales No. 3099067

5 Howick Place | London | SW1P 1WG 
journal

\section{Asian Studies Review >}

\section{This journal}

\section{Editorial board}

Editor In Chief:

David Hundt - Deakin University (incoming)

Assistant Editor:

Anne Platt - University of Queensland

\section{Editorial Assistant:}

Vanessa Smith - Deakin University

\section{Regional Editors (articles):}

Central and West Asia: Luca Anceschi - University of Glasgow

China: Jonathan Benney - Monash University

Japan: Rebecca Suter - University of Sydney

Korea: Jiyoung Song - University of Melbourne

Mainland Southeast Asia: Tyrell Haberkorn - Australian National University

Maritime Southeast Asia: Robbie Peters - University of Sydney

South Asia: Priya Chacko - University of Adelaide

Thematic Editors (articles):

Gender and Sexuality: Laura Dales - University of Western Australia International History: Jason Lim - University of Wollongong International Relations: David Walton - University of Western Sydney Language and Education: Kayoko Hashimoto - University of Queensland 
Media and Culture: Terence Lee - Murdoch University

Migration: Susanne Schech - Flinders University

Political Economy and International Politics: Toby Carroll - City University of Hong Kong

\section{Reviews Editors (book reviews and review articles):}

Central and West Asia: David Radford - University of South Australia

China: Andres Rodriguez - University of Sydney

Culture, Gender and Sexuality: Claire Maree - University of Melbourne International History:Huiyun Feng - Griffith University

International Relations and Migration: Melissa Curley - University of Queensland

Japan: Rebecca Suter - University of Sydney

Korea: Jiyoung Song - University of Melbourne

Language and Education: Kayoko Hashimoto - University of Queensland

South Asia: Trent Brown - University of Melbourne

Southeast Asia: Ken Setiawan - University of Melbourne

\section{International Advisory Board}

Pam Allen - University of Tasmania

Tim Allender - University of Sydney

Ien Ang - University of Western Sydney

Chris Berry - Goldsmiths College University of London

Susan Blackburn - Monash University

Dipesh Chakrabarty - University of Chicago

Joseph Cheng - City University of Hong Kong

Chua Beng Huat - National University of Singapore

Helen Creese - University of Queensland

Robert Cribb - Australian National University

Stephanie Donald - RMIT University

Louise Edwards - University of New South Wales

Antonia Finnane - University of Melbourne

Nannette Gottlieb - University of Queensland

Vedi Hadiz - Melbourne University

Helen Hardacre - Harvard University

Rachel Harrison - SOAS University of London

Ariel Heryanto - Australian National University

Josephine Ho - National Central University Taiwan 
Paul Hutchcroft - Australian National University

Koichi Iwabuchi - Waseda University

Peter Jackson - Australian National University

Bruce Jacobs - Monash University

Purnendra Jain - University of Adelaide

Robin Jeffrey - Asian Research Institute Singapore

O. Yul Kwon - Griffith University

Kam Louie - University of Hong Kong

Vera Mackie - Wollongong University

Jim Masselos - University of Sydney

Meaghan Morris - University of Sydney

Lyn Parker - University of Western Australia

Kalpana Ram - Macquarie University

Tony Reid - Australian National University

Abdullah Saeed - University of Melbourne

Krishna Sen - University of Western Australia

Sanjay Seth - Goldsmiths College University of London

Maila Stivens - University of Melbourne

Philip Taylor - Australian National University

Adrian Vickers - University of Sydney

Wang Gangwu - National University of Singapore

Sign in here

to start your access

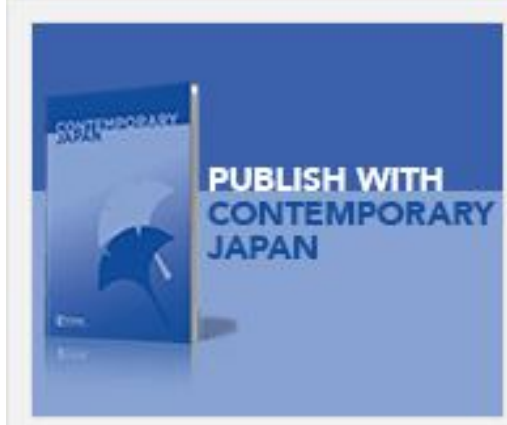




\section{Open Access Bulletin}

\section{Sign up here}

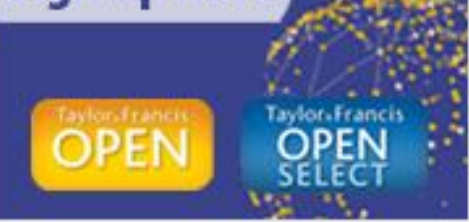

Information for

Authors

Editors

Librarians

Societies

Help and info

Help

FAQS

Press releases

Contact us

Commercial services
Open access

Overview

Open journals

Open Select

Cogent OA

Connect with Taylor \& Francis

f日in

You

Copyright $\odot 2017$ Informa UK Limited Privacy policy \& cookies Terms \& conditions Accessibility

Registered in England \& Wales No. 3099067

5 Howick Place | London | SW1P 1WG 
Journal

Asian Studies Review >

Explore

This journal

\title{
Latest articles
}

\author{
Notes on Contributors
}

Contributors >

Published online: 22 Jan 2018

\begin{tabular}{l|l|l}
0 & 0 & 0 \\
Views & CrossRef citations & Altmetric
\end{tabular}

Original Articles

Article

Contesting Disciplinary Power: Transnational Domestic Labour in the Global South >

Linda A. Lumayag

Published online: 17 Jan 2018

\begin{tabular}{l|l|l}
7 & 0 & 9 \\
Views & CrossRef citations & Altmetric
\end{tabular}




\section{Article}

Migration, Moralities and Moratoriums: Female Labour Migrants and the Tensions of Protectionism in Indonesia >

Maria Platt

Published online: 17 Jan 2018

\begin{tabular}{l|l|l}
1 & 1 & 0 \\
Views & CrossRef citations & Altmetric
\end{tabular}

\section{Article}

The Trap of Neo-patrimonialism: Social Accountability and Good Governance in Cambodia >

Danilo Vuković \& Marija Babović

Published online: 17 Jan 2018

\begin{tabular}{l|l|l}
\hline 1 & 0 & 0 \\
Views & CrossRef citations & Altmetric
\end{tabular}

Article

Virtually (Im)moral: Pious Indonesian Muslim Women's Use of Facebook >

Hanny Savitri Hartono

Published online: 16 Jan 2018

\begin{tabular}{l|l|l|}
\hline 7 & 1 & 0 \\
Views & CrossRef citations & Altmetric
\end{tabular}

Introduction 
Introduction

Contestations of Gender, Sexuality and Morality in Contemporary Indonesia >

Maria Platt, Sharyn Graham Davies \& Linda Rae Bennett

Published online: 10 Jan 2018

\begin{tabular}{l|l|l}
378 & 1 & 1 \\
Views & CrossRef citations & Altmetric
\end{tabular}

Original Articles

Article

Power List Reform: A New Constraint Mechanism for Administrative Powers in China >

Hong Gao \& Adam Tyson

Published online: 10 Jan 2018

\begin{tabular}{l|l|l}
8 & 0 & 0 \\
Views & CrossRef citations & Altmetric
\end{tabular}

\section{Article}

From Divine Instruction to Human Invention: The Constitution of Indonesian Christian Young People's Sexual Subjectivities through the Dominant Discourse of Sexual Morality >

Teguh Wijaya Mulya

Published online: 07 Jan 2018

\begin{tabular}{l|l|l}
\hline 11 & 0 & 0 \\
Views & CrossRef citations & Altmetric
\end{tabular}

Article 
Skins of Morality: Bio-borders, Ephemeral Citizenship and Policing Women in Indonesia >

Sharyn Graham Davies

Published online: 07 Jan 2018

\begin{tabular}{l|l|l|}
46 & 0 & 2 \\
Views & CrossRef citations & Altmetric
\end{tabular}

\section{Article}

Moralising Rhetoric and Imperfect Realities: Breastfeeding Promotions and the Experiences of Recently Delivered Mothers in Urban Yogyakarta, Indonesia >

Belinda Rina Marie Spagnoletti, Linda Rae Bennett, Michelle Kermode \& Siswanto Agus Wilopo Published online: 07 Jan 2018

36

Views CrossRef citations Altmetric

\section{Article}

Dynamics of Nuclear Power Policy in the Post-Fukushima Era: Interest Structure and Politicisation in Japan, Taiwan and Korea >

Sung Chull Kim \& Yousun Chung

Published online: 15 Dec 2017

\begin{tabular}{l|l|l}
192 & 0 & 2 \\
Views & CrossRef citations & Altmetric
\end{tabular}

Book Review

Book review

Exile in colonial Asia: kings, convicts, commemoration >

Anthony H. Johns 
Published online: 03 Sep 2017

\begin{tabular}{l|l|l}
17 & 0 & 0 \\
Views & CrossRef citations & Altmetric
\end{tabular}

Book review

Spectacular accumulation: material culture, Tokugawa Ieyasu, and samurai sociability >

Olivier Ansart

Published online: 31 Aug 2017

\begin{tabular}{l|l|l}
\hline 15 & 0 & 0 \\
Views & CrossRef citations & Altmetric
\end{tabular}

Book review

Curriculum, instruction and assessment in Japan: beyond lesson study >

Peter Cave

Published online: 31 Aug 2017

\begin{tabular}{l|l|l}
\hline 10 & 0 & 0 \\
Views & CrossRef citations & Altmetric
\end{tabular}

Book review

Languages in the Malaysian education system: monolingual strands in multilingual settings >

Zuwati Hasim

Published online: 03 May 2017

\begin{tabular}{l|l|l}
26 & 0 & 0 \\
Views & CrossRef citations & Altmetric
\end{tabular}




\section{Book review}

Activism and aid: young citizens' experiences of development and democracy in Timor-Leste >

Natali Jane Pearson

Published online: 26 Apr 2017

\begin{tabular}{l|l|l}
20 & 0 & 0 \\
Views & CrossRef citations & Altmetric
\end{tabular}

Book review

A Chinese traveler in medieval Korea: Xu Jing's illustrated account of the Xuanhe embassy to Koryŏ >

Dennis Lee

Published online: 26 Apr 2017

\begin{tabular}{l|l|l}
\hline 10 & 0 & 0 \\
Views & CrossRef citations & Altmetric
\end{tabular}

Book review

Archipelago: a journey across Indonesia >

Natali Jane Pearson

Published online: 26 Apr 2017

\begin{tabular}{l|l|l}
\hline 15 & 0 & 0 \\
Views & CrossRef citations & Altmetric
\end{tabular}

Book review

Mobile citizens: French Indians in Indochina, 1858-1954 > 
Robert Aldrich

Published online: 26 Apr 2017

\begin{tabular}{l|l|l}
12 & 0 & 0 \\
Views & CrossRef citations & Altmetric
\end{tabular}

Sign in here

to start your access
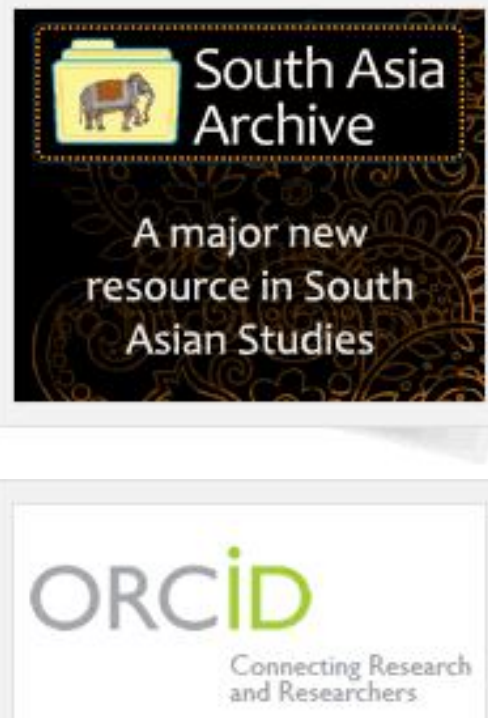

Get your unique ORCID author identfier and start compiling your research record 


\section{SJR}

Scimago Journal \& Country Rank Enter Journal Title, ISSN or Publisher Name

Home Journal Rankings Country Rankings Viz Tools Help About Us

\section{Asian Studies Review}

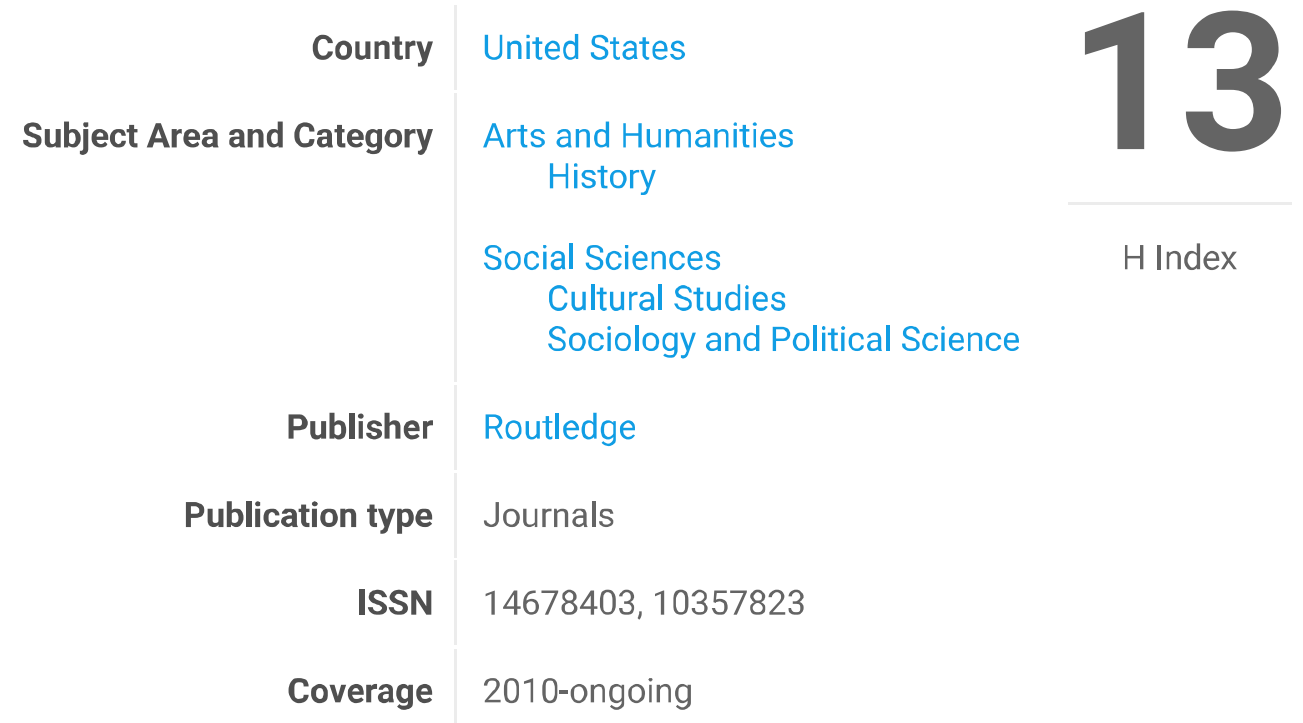

Quartiles

Cultural Studies

History

Sociology and Political Science

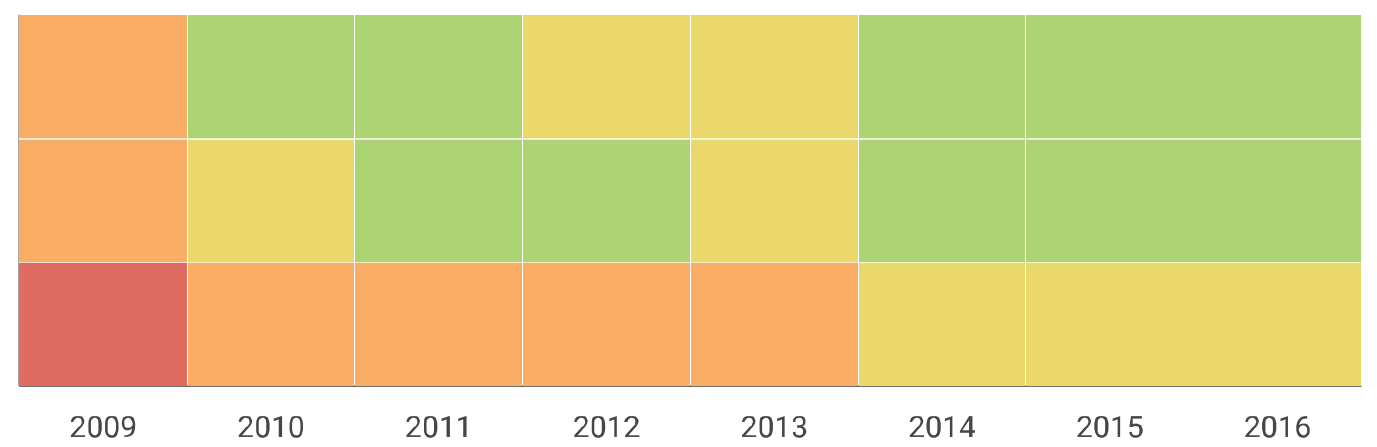

SJR

$+\quad$ Citations per document

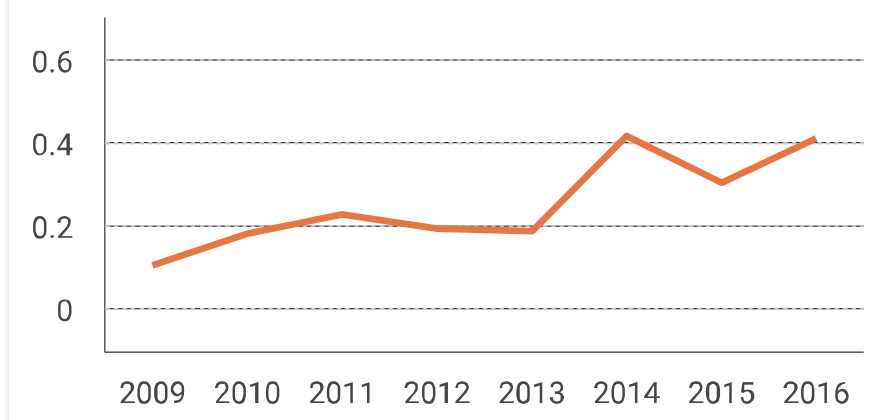

Total Cites

Self-Cites 

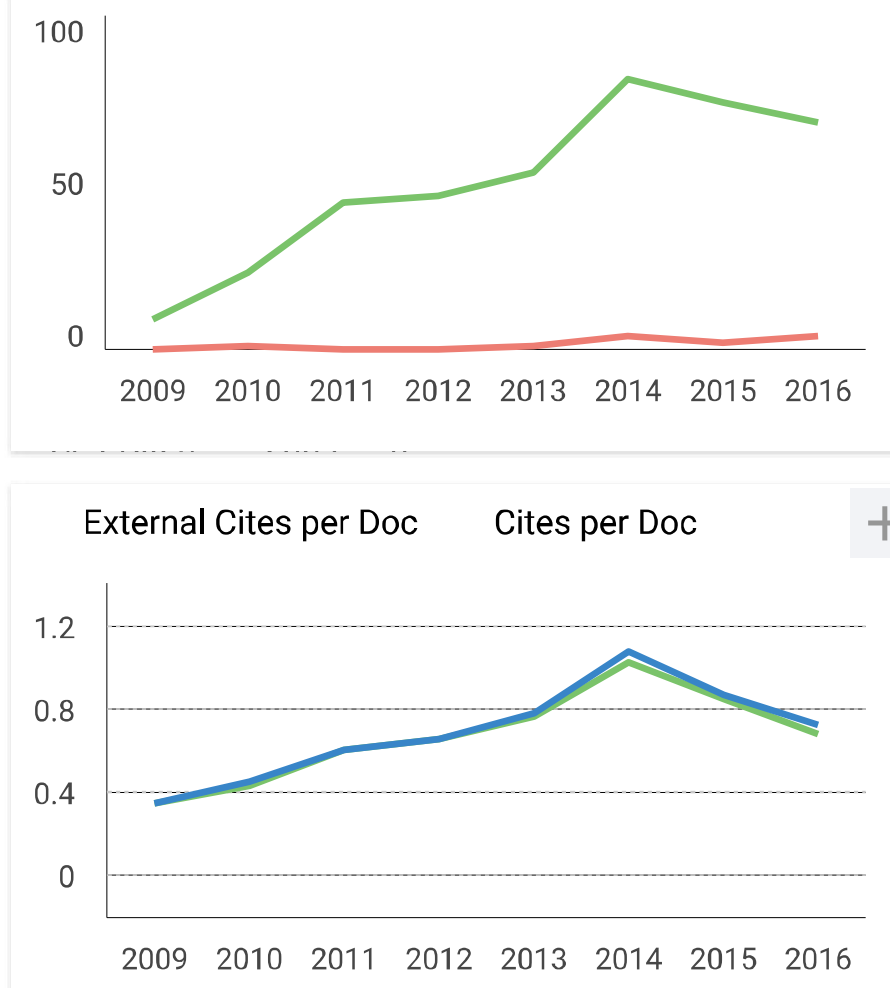

Citable documents Non-citable documents $\quad+$
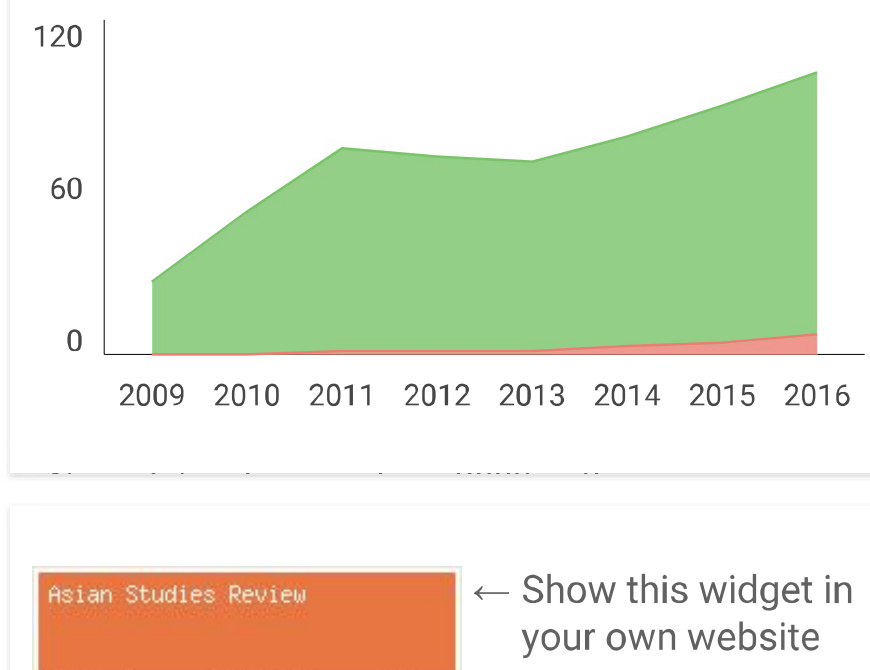

$\leftarrow$ Show this widget in your own website

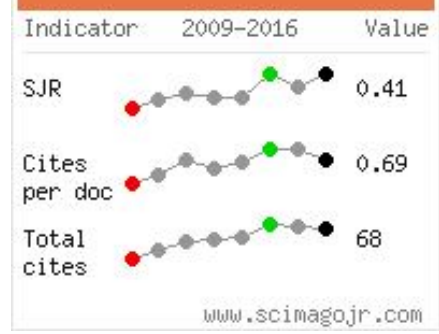

Just copy the code below and paste within your html code:

$<\mathrm{a}$ href="http://www.scimagi

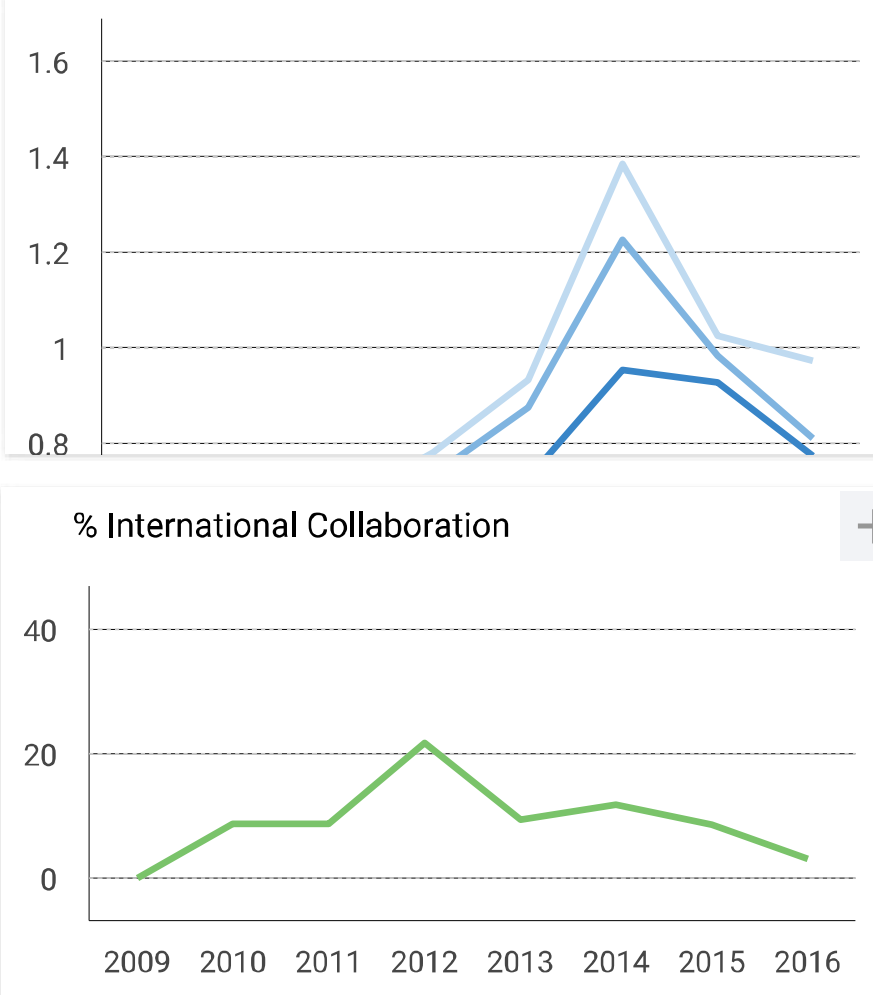

Cited documents Uncited documents

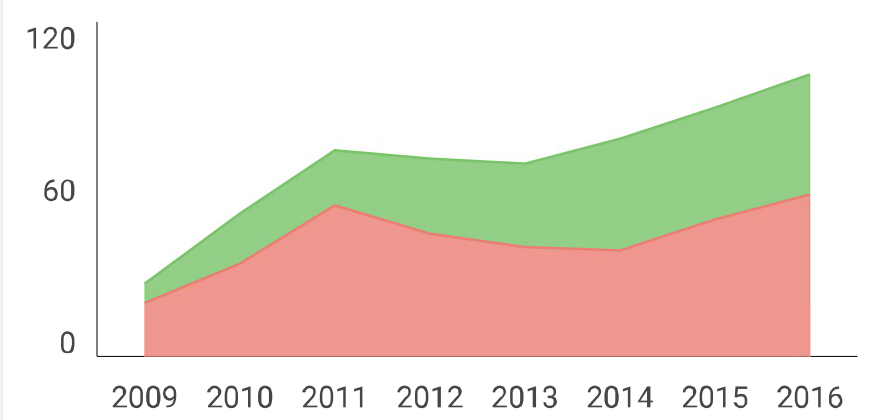


Developed by:

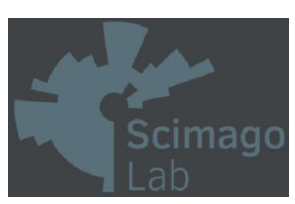

Follow us on Twitter

Scimago Lab, Copyright 2007-2017. Data Source: Scopus ${ }^{\circledR}$

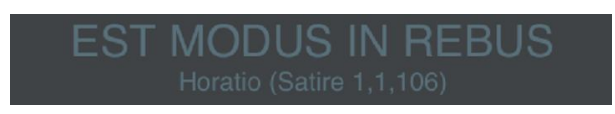

